\title{
A Tutela Jurisdicional como instrumento de concretização da democracia: a evolução do Estado Social ao Estado Democrático de Direito
}

\section{Jurisdicional Guardianship as na instrument for the realization of Democracy: the Evolution of the social state to the Democratic rule of law}

\author{
Priscila Anselmini ${ }^{1}$
}

Paulo Júnior Trindade dos Santos ${ }^{2}$

\begin{abstract}
RESUMO:
O presente trabalho busca analisar a tutela jurisdicional como instrumento útil e eficaz para concretizar a democracia. Para isso, analisar-se-á a evolução do processo desde o Estado Social até o surgimento do Estado Democrático de Direito, que se funda na participação paritária dos sujeitos processuais, na dialeticidade processual e nos princípios constitucionais, como o contraditório. Em termos gerais, o artigo aborda a possibilidade de concretizar a democracia, por meio da tutela jurisdicional, repensando o processo sob o viés da democracia participativa, a fim de ter uma maior participação do cidadão como sujeito processual, garantindo-se os direitos fundamentais.
\end{abstract}

\section{PALAVRAS-CHAVE:}

Tutela Jurisdicional; Estado Democrático de Direito; Democracia Participativa; Contraditório; Dialeticidade Processual.

\begin{abstract}
:
The present work seeks to analyse judicial tutelage as a useful and effective tool for achieving democracy. For this, the process will be analyzed from the Social state to the emergence of the democratic State of law, which is founded on the joint participation of procedural subjects, procedural dialeticidade and constitutional principles, such as Contradictory. In general terms, the article addresses the possibility of achieving democracy through judicial guardianship, rethinking the process under the bias of participatory democracy, in order to have a greater participation of the citizen as a procedural subject, ensuring the Fundamental rights.
\end{abstract}

\footnotetext{
${ }^{1}$ Bolsista Capes/PROEX do Curso de Mestrado em Direito Público pela UNISINOS; Especialista em Direito Público pela ESMAFE/RS; Assessora jurídica da Prefeitura Municipal de Barão/RS; Advogada na área de Direito Empresarial e Tributário. Foi Monitora e Pesquisadora da Universidade do Vale do Rio dos Sinos, atuando principalmente nos seguintes temas: tributação; desigualdade de renda; progressividade; neoliberalismo.

${ }^{2}$ Pós-doutorando, Doutor e Mestre em Direito Público com ênfase em Direito Processual Civil pela UNISINOS, com Bolsa CAPES - CNPq remunerada. Representante de Discentes do ora Curso (2011- até o momento). PósGraduando na Especialização em Direito Processual Civil e Trabalhista pela Associação dos Magistrados Trabalhistas da 12 Região (AMATRA12). Graduação em Direito pela Universidade do Oeste de Santa Catarina (UNOESC - 2009-02). Pesquisador/Investigador Jurídico nas áreas: 1) Direito Público com ênfase em "Teoria Geral do Estado e do Direito Constitucional" e em Direito Processual Civil; 2) Direito Privado: ênfase em Direito Civil e sua Contemporaneidade; 3) Constitucionalização do Direito; e 4) Filosofia do-no Direito.
} 


\section{KEYWORDS:}

Judicial guardianship; Democratic State of law; Participatory democracy; Contradictory Procedural Dialeticidade.

\section{INTRODUÇÃO}

O presente trabalho busca analisar como a tutela jurisdicional pode ser um instrumento útil e eficaz para concretizar a democracia. Para isso, se realizou um resgate da evolução do processo frente ao modelo de Estado Social e o atual Estado Democrático de Direito.

Devido a insatisfação social resultante do liberalismo processual, surgiram paradigmas processuais típicos do Welfare State, com o advento de linhas doutrinárias defendidas por Anton Menger, Franz Klein e Oscar Von Bülow. Menger defendia uma atividade jurisdicional compensadora das desigualdades sociais, por meio do juiz social. Klein preconizava a oralidade no processo, sendo o juiz o responsável pela direção do processo. Assim, resultou no enfraquecimento dos outros sujeitos processuais. Esse protagonismo judicial também era defendido por Bülow, como se verá no decorrer do trabalho.

Mediante o surgimento de novas linhas na teoria do direito e do Estado Democrático de Direito, embasado na proteção dos direitos fundamentais e na soberania do povo, defendeu-se a quebra do protagonismo judicial, através de uma participação paritária dos sujeitos processuais, na formação de um processo constitucional, calcado na dialeticidade processual e nos princípios como, o contraditório, juiz natural, devido processo legal, entre outros.

Dessa forma, o trabalho busca verificar como o processo pode ser um meio à população para concretizar e efetivar seus direitos perante o Estado, quando este não os garante, permitindo que a democracia se concretize através da participação popular. Para tanto, empregou-se na pesquisa, como recurso técnico, as fontes bibliográficas nacionais e estrangeiras, abrangendo fundamentalmente fontes jurídicas, tais como: livros jurídicos, 
relatórios oficiais e fontes jurisprudenciais. Ainda, utilizaram-se grandes obras de Direito, referenciadas ao final do trabalho.

O objetivo geral deste trabalho, então, é analisar a evolução da tutela jurisdicional, a fim de explicar como o processo, frente ao Estado Democrático de Direito, pode ser um instrumento para concretizar a democracia, por meio da participação popular e da dialeticidade processual.

Como objetivos específicos buscar-se-á analisar, primeiramente, o Modelo de Estado Social e explorar as teorias processuais defendidas pelos principais doutrinadores do socialismo processual. Em seguida, ir-se-á abordar as principais alterações processuais frente ao Estado Democrático de Direito, estudando os conceitos de democracia representativa e participativa, para, posteriormente, verificar se o processo pode ser um instrumento efetivo na concretização da democracia, por meio de seus princípios constitucionais, como o princípio do contraditório.

No atual cenário político e social, percebe-se que a democracia encontra-se em crise, através do descrédito da população na forma de governar dos agentes políticos, bem como na falha do Estado em garantir à todos o acesso aos direitos fundamentais. Para tanto, a tutela jurisdicional pode auxiliar a população na busca por seus direitos, por meio de um processo baseado na participação paritária entre os sujeitos processuais e na dialeticidade-diálogo processual.

Por tudo isso, a pesquisa a ser desenvolvida mostra-se de suma importância para a verificação da real possibilidade de se garantir a concretização da democracia, por meio da tutela jurisdicional, repensando o processo sob o viés da democracia participativa, a fim de ter uma maior participação do cidadão como sujeito processual, garantindo-se os direitos fundamentais.

\section{O SURGIMENTO DO SOCIALISMO PROCESSUAL}

O modelo de Estado Social surge após a Primeira Guerra Mundial, mas se firma se firma após a Segunda. Este modelo intervém na economia, através de uma proposta de bem-estar 
(Welfare State), que implica uma manutenção artificial da livre concorrência e da livre iniciativa, assim como a compensação das desigualdades sociais através da prestação estatal de serviços e da concessão de direitos sociais.

Essa ruptura paradigmática vem redefinir os clássicos direitos da vida, liberdade, propriedade, segurança e igualdade. É a chamada "materialização" do direito, em que a Administração Pública possui o papel de garantir aos cidadãos o acesso aos bens e serviços. $\mathrm{O}$ direito passa a ser interpretado como sistema de regras e princípios otimizáveis, consubstanciadores de valores fundamentais, bem como de programas de fins, realizáveis no "limite do possível. ${ }^{3}$

Desse modo, com o fim do século XIX, surgiram novas concepções que modificaram não só o modelo de Estado, mas também o pensamento jurídico-processual. Foi neste período a transição entre o liberalismo processual e socialismo processual.

No socialismo processual o processo passa a ser

[...] instrumento técnico de resolução de conflitos, dentro do qual o juiz se apresentaria como um canal de comunicação e expressão do sentimento da sociedade, dispondo de respaldo institucional para ser o protagonista com poderes privilegiados de direção e participação ativa no processo (ao contrário da passividade judicial idealizada pelos liberalistas). ${ }^{4}$

O modelo de Estado Social contribuiu para que se repensassem a tutela jurisdicional, típica do Modelo Liberal de Estado. Assim, surgem importantes juristas, como Anton Menger, Franz Klein e Bulow, que participaram na evolução da tutela jurisdicional como um todo. Dessa forma, passar-se-á analisar a contribuição jurídica destes juristas na formação do socialismo processual.

3 CATTONi DE OlIVEIRA, Marcelo Andrade. Direito Processual Constitucional. Belo Horizonte: Mandamentos, 2001, p. 59.

4 ANDRADE, Francisco Rabelo Dourado de. FARIA, Guilherme Henrique Lage. O modelo social de processo: suas conjecturas sobre suas origens, desenvolvimento e crise frente ao novo paradigma do Estado Democrático de Direito. Disponível em: < http://www.publicadireito.com.br/artigos/?cod=c59115e88a6dbe2f>Acesso em 05 jul. 2018. P. 4 


\subsection{Anton Menger}

Anton Menger (1841-1906) foi um jurista austríaco, partidário de reformas sociais e um dos representantes do socialismo jurídico. O jurista tinha como objetivo criar um sistema de transformação puramente jurídica, legislativa, do regime capitalista em socialista.

Menger criticava os ideais liberais, afirmando que a igualdade formal acabava favorecendo os ricos em detrimento dos mais pobres. Dessa forma, ele propõe uma reforma na justiça civil, mediante um reforço do papel judicial. ${ }^{5}$

Neste modelo de processo, há uma tendência a declinar o contraditório, em que o Juiz alcança a verdade "absoluta", mesmo que fora da estrutura do contraditório, assumindo uma autoridade e hierarquia dentro do processo.

Assim, o Juiz atua desde a organização inteligível dos elementos do litigio até os esforços máximos de negociação entre as partes, proporcionando uma solução célere, não litigiosa e consensualmente justa.

O juiz é o intérprete que possui sensibilidade na busca solitária do bem comum, assegurando um privilégio na formação do provimento de resolução dos conflitos a ele submetidos. ${ }^{6}$

Desse modo, para Dierle José Coelho Nunes, o juiz no socialismo processual é:

[...] um protagonista do processo, que constrói provimentos solitariamente, sem a influência dos demais sujeitos processuais e, especialmente, sem a chancela técnica do processo, uma vez que a busca pela rapidez procedimental conduziria à construção de procedimentos cognitivos que reduzem a dialogicidade e avalizam o solipsismo judicial. $^{7}$

\footnotetext{
5 JOSÉ COELHO NUNES, Dierle. Comparticipação e Policentrismo: horizontes para a democratização do Processo Civil. Tese (Doutorado)- Pontifica Universidade Católica de Minas Gerais. Programa de Pós-Graduação em Direito. Belo Horizonte, 2008. P. 49.

${ }^{6}$ DINAMARCO, Cândido Rangel. A instrumentalidade do processo. São Paulo: Malheiros, 2001.

${ }^{7}$ JOSÉ COELHO NUNES, Dierle. Comparticipação e Policentrismo: horizontes para a democratização do Processo Civil. Tese (Doutorado)- Pontifica Universidade Católica de Minas Gerais. Programa de PósGraduação em Direito. Belo Horizonte, 2008. P. 48
} 
No Welfare State o Estado possui a função garantidor de serviços e bens à população, a fim de compensar as desigualdades sociais. Neste sentido deve ser o papel do juiz na tutela jurisdicional, assumindo a posição de educador e representante dos pobres.

Segundo Anton Menger o julgador tem a função de educador no processo, pois deveria instruir os cidadãos acerca do direito vigente, de modo a auxiliá-los na defesa de seus direitos. O jurista afirma que o juiz também possui o papel de representante dos pobres, já que assume a representação da classe mais pobre. Assim, o julgador assumiria uma postura compensadora dos déficits de igualdade material das partes, na verdadeira acepção do termo “juiz social”. 8

Acerca do papel de representante dos pobres, Anton Menger afirma que, quando o rico fosse representado por advogado, o juiz deveria proceder o equilíbrio das partes, representando o mais pobre. Isso requereria uma reconstrução das leis relativas às funções dos tribunais, sendo confiadas as funções judiciais aos advogados dos pobres, que era nomeados e pagos pelo Estado. ${ }^{9}$

A ideia de que estaria a cargo do juiz social a busca por equilíbrio (igualdade) no processo, também era o pensamento de Franz Klein, que defendia uma reestruturação do papel das partes e dos juízes no iter procedimental no Direito Processual. Assim, o processo deveria ser uma instituição estatal de bem-estar social, que deveria proporcionar à sociedade uma jurisdição célere, por meio de uma técnica procedimental embasada no protagonismo decisório. $^{10}$

\subsection{Franz Klein e a oralidade no processo}

As ideias defendidas por Menger, sobre as alterações necessárias ao processo frente ao Estado Social, foram de extrema relevância para a formação da primeira legislação

\footnotetext{
8 ANDRADE, Francisco Rabelo Dourado de. FARIA, Guilherme Henrique Lage. O modelo social de processo: suas conjecturas sobre suas origens, desenvolvimento e crise frente ao novo paradigma do Estado Democrático de Direito. Disponível em: < http://www.publicadireito.com.br/artigos/?cod=c59115e88a6dbe2f > Acesso em 05 jul. 2018. P. 6

${ }^{9}$ MENGER, Anton. El derecho civil e los pobres. Atalya: Buenos Ayres, 1947, p. 69.

10 ANDRADE, Francisco Rabelo Dourado de. FARIA, Guilherme Henrique Lage. O modelo social de processo: suas conjecturas sobre suas origens, desenvolvimento e crise frente ao novo paradigma do Estado Democrático de Direito. Disponível em: < http://www.publicadireito.com.br/artigos/?cod=c59115e88a6dbe2f> Acesso em 05 jul. 2018. P. 6
} 
socializadora, a Ordenança Processual Civil do Império Austro-Húngaro, de 1895, a famosa ÖZPO.

A OZPO foi obra de Franz Klein, aluno de Anton Menger Klein defendia que o julgador deveria auxiliar as partes na busca do clareamento dos requerimentos obscuros, assim, o processo seria uma "instituição estatal de bem-estar social”, a fim de pacificar os conflitos sociais. ${ }^{11}$

Dessa forma, o Processo social não se resume em pretensões materiais ou direitos subjetivos das partes, alcançando também o interesse da comunidade a um acesso mais equânime e universal à ordem jurídica justa e a uma eficiente organização do processo civil assistencial.

Neste sentido, Klein afirmava ser necessária uma reestruturação no papel das partes e do juiz no processo, sendo que caberia às partes trazer ao processo a descrição dos fatos, mas a participação essencial do Juiz na fase de alegações e provas, decidindo como a verdadeira situação jurídica exige. ${ }^{12}$

Como Cappelletti afirma esse modelo proposto por Franz Klein preconizava a oralidade, com uma relação direta entre o órgão decididor e as partes e testemunhas, cabendo ao juiz uma valoração crítica das provas trazidas ao processo. Assim, aumentou-se a função ativa do juiz, assegurando a ordem e rapidez do procedimento, bem como a igualdade entre as partes. ${ }^{13}$

Assim, o juiz deveria auxiliar as partes, esclarecendo fatos obscuros, ajudando a preencher detalhes incompletos e impedindo que isso prejudicasse as partes no julgamento. ${ }^{14}$

O processo era visto como uma instituição estatal de bem-estar social e, caso houvesse uma crise social, o Estado deveria intervir em todas as fases do processo. Como o autor afirma:

\footnotetext{
${ }^{11}$ NUNES, Dierle José Coelho. Processo Jurisdicional Democrático. Curitiba: Juruá, 2008, p. 83.

12 KLEIN, Franz. Zeit- und Geistesströmungen im prozesse. Frankfurt am Main: Vitorio Klostermann, 1958 , p. 16

${ }^{13}$ CAPPELleTtI, Mauro. Processo, ideologias e sociedade; tradução e notas do Prof. Dr. Elício de Cresci Sobrinho. - Porto Alegre: Sergio Antonio Fabris Ed., 2008, p. 321-322.

${ }^{14}$ KLEIN, Franz. Zeit- und Geistesströmungen im prozesse. Frankfurt am Main: Vitorio Klostermann, 1958 , p. 17.
} 
"Precisa-se apenas libertar as forças atadas do Juiz e colocá-las, assim como as demais forças do órgão estatal, a serviço do direito, do bem comum e da paz social." 15

Para tanto, era necessário novas técnicas legislativas, com a adoção de certos conceitos:

\begin{abstract}
A legislação se contenta com a metade do trabalho e joga a outra metade sobre os ombros do juiz, que tem de escolher, dentre o grande número de possibilidades que estão subordinadas ao conceito em si e para si, aquela para a qual a norma jurídica deve valer dentro do espírito da lei. As linhas abordadas de tais indícios fáticos deixam considerável espaço para o pensamento original, que é próprio apenas dele, do juiz. A jurisdição se torna tanto mais pessoal, já que nos determinados casos limite, pode o juiz, em um, ter que se submeter ao conceito legal e, em outros, eliminá-los sem que seu dever venha a ferir qualquer um desses casos-limite, pois é justamente apenas em seu saber que cada um vê, pensa, decide e julga. ${ }^{16}$
\end{abstract}

Influenciado por Menger, Klein propõe diminuir a demora exacerbada das demandas provenientes do modelo liberal de processo por meio de uma jurisdição célere, sendo necessário estruturar um modelo técnico de procedimento oral em que se atribuiu um reforço dos poderes do juiz, o qual deveria participar mais densamente da direção do processo. ${ }^{17}$

Dessa forma, ideias preconizadas por Klein influenciaram o processo alemão, introduzindo medidas que reduzissem o lapso temporal entre a propositura da ação e a prolação da sentença.

Assim, objetivou um processo mais célere, efetivo e dirigido por juízes com poderes mais amplos na condução, na intervenção e na correção do processo. Assim, essa rapidez processual é exigida pelo caráter de bem público dessa instituição. ${ }^{18}$

Essa autuação assistencial mais efetiva do juiz, a partir do modelo legislativo introduzido por Klein, permitiu a implementação do discurso do protagonismo judicial, que influenciou o sistema processual de diversos países.

\footnotetext{
15 KLEIN, Franz. Zeit- und Geistesströmungen im prozesse. Frankfurt am Main: Vitorio Klostermann, 1958 , p. 28.

${ }^{16}$ NUNES, Dierle José Coelho. Processo Jurisdicional Democrático. Curitiba: Juruá, 2008, p.84-85.

17 ANDRADE, Francisco Rabelo Dourado de. FARIA, Guilherme Henrique Lage. O modelo social de processo: suas conjecturas sobre suas origens, desenvolvimento e crise frente ao novo paradigma do Estado Democrático de Direito. Disponível em: < http://www.publicadireito.com.br/artigos/?cod=c59115e88a6dbe2f > Acesso em 05 jul. 2018. P. 7

${ }^{18}$ SPRUNG, Rainer. Os fundamentos do processo civil austríaco. Revista de Processo, São Paulo. Revista dos Tribunais, $\mathrm{n}^{\circ} 17$, p. 148, jan./mar. 1980.
} 
A primeira legislação a sofrer a interferência de seus ideais foi a ZPO alemã, com alterações em 1909, 1924 e 1933. A reforma de 1924 avigora os poderes judiciais formais e matérias, retirando das partes o controle dos prazos e atribuindo ao juiz uma participação mais efetiva no processo. ${ }^{19}$

A ZPO alemã foi criada em pleno regime nazista, a qual buscava uma justiça rápida e mais próxima das exigências do povo, partindo da ideia de que a função jurisdicional não servia somente às partes, mas primeiramente à segurança jurídica da coletividade. ${ }^{20}$

Na concepção de $\mathrm{Maus}^{21}$, o juiz alemão passa a ser, dessa forma, o protetor dos valores do regime nazista incutidos no povo e aniquilador dos fatos e valores contrários de um povo doente. O juiz alemão deveria aplicar a lei com o espírito do povo, mas de acordo com a vontade jurídica de Hitler.

Na Itália, as influências de Klein chegaram a partir da metade do século XX, em pleno regime fascista, com predomínio do princípio autoritário, em que as bases do Estado deveriam fazer presentes também no processo civil, representado pelo juiz, reforçando seus poderes. ${ }^{22}$

Logo, o juiz detinha poderes de inciativa, destinados a preencher as lacunas da defesa, bem como sugerir uma solução às partes menos preparadas. ${ }^{23}$

No Brasil, essa tendência inicia-se com Código de Processo Civil de 1939, com nítida vocação totalitária, populista e paternalista, inspirado nos ideais de Getúlio Vargas. Entretanto a característica de oralidade não se implementou de fato no processo brasileiro, apenas reforçou

\footnotetext{
${ }^{19}$ JOSÉ COELHO NUNES, Dierle. Comparticipação e Policentrismo: horizontes para a democratização do Processo Civil. Tese (Doutorado)- Pontifica Universidade Católica de Minas Gerais. Programa de PósGraduação em Direito. Belo Horizonte, 2008. P. 56.

${ }^{20}$ TROCKER, Nicolo. Processo Civile e Costituzione. Probleme de diritto tedesco e italiano. Milano: Giuffrè, 1974, p. 55.

${ }^{21}$ MAUS, Ingeborg. Judiciário como superego da sociedade: o papel da atividade jurisprudencial da "sociedade órfã. Novos estudos CEBRAP, n. 58, p. 97-98, nov. 2000.

${ }^{22}$ CALAMANDREI, Piero. Sul progetto preliminar Solmi. Studi sul processo civile. Padova: CEDAM, 1939, v. IV, p. 115-118.

${ }^{23}$ DENTI, Vittorio. Processo Civile e giutizia sociale. Milano: Edizione di Comunità, 1971, p. 20.
} 
o papel e superioridade da magistratura, mas a condução do procedimento se deu como se a legislação fosse liberal. ${ }^{24}$

Além das influências de Menger e Klein para tutela jurisdicional, Bulow também foi um importante doutrinador na Teoria Social do Processo, no que tange ao protagonismo judicial, como ver-se-á no próximo tópico.

\subsection{Bulow e o protagonismo judicial}

O propósito de Bülow foi apresentar fundamentos histórico-sociológicos para a legitimação do controle social pela magistratura alemã e de justificar a adoção de técnicas que permitissem a desvinculação dos julgadores dos métodos formalistas ou legalistas da aplicação do direito. ${ }^{25}$

Dessa forma, o doutrinador deu origem à autonomia do Direito Processual Civil quando afirma que,

[...] a relação jurídica processual se distingue das demais relações de direito por outra característica singular, que pode ter contribuído, em grande parte, ao desconhecimento de sua natureza de relação jurídica contínua. ${ }^{26}$

Logo, Bulow defende o protagonismo judicial, alegando que há um direito próprio e verdadeiro de origem judicial, ao lado do direito criado pela lei, mas que não se confunde com o direito consuetudinário. ${ }^{27}$

\footnotetext{
${ }^{24}$ JOSÉ COELHO NUNES, Dierle. Comparticipação e Policentrismo: horizontes para a democratização do Processo Civil. Tese (Doutorado)- Pontifica Universidade Católica de Minas Gerais. Programa de PósGraduação em Direito. Belo Horizonte, 2008, p. 64-65.

25 ANDRADE, Francisco Rabelo Dourado de. FARIA, Guilherme Henrique Lage. O modelo social de processo: suas conjecturas sobre suas origens, desenvolvimento e crise frente ao novo paradigma do Estado Democrático de Direito. Disponível em: < http://www.publicadireito.com.br/artigos/?cod=c59115e88a6dbe2f> Acesso em 09 jul. 2018. P. 15

${ }^{26}$ BÜLOW, Oskar, Teoria das Exceções Processuais e dos pressupostos processuais. Campinas: LZN, 2005, p. $5-6$.

${ }^{27}$ BÜLOW, Oskar. Gesetz und Richeteramt. Juritsche Zeitgeschichte. Berlem: Berliner Wissenschafts, 2003, v. 10, p. $7-8$.
} 
Como protagonista do processo, o autor defende ao Estado é dever suportar e munir as decisões proferidas pelo juiz, bem como tornar juridicamente vinculante decisão contrária à norma. Logo, a decisão do juiz é uma norma que emana do Estado, com poder coercitivo. ${ }^{28}$

Bulow vê o processo como mero instrumento de viabilização hipoteticamente emancipatório pela atividade criadora do direito pela magistratura, em que a formação e a existência do processo deveriam ser controladas pelo juiz, através de vínculos de subordinação. 29

Assim, ao juiz cabia o comando e controle da relação processual e, consequentemente, de todo o direito vigente, através da possibilidade de criação de normas pelo julgador, sendo as partes meros colaboradores do juízo na formação do provimento. ${ }^{30}$

A teoria de Bülow sobre o protagonismo judicial defende a superioridade do julgador em relação aos sujeitos do processo, em que o contraditório é relegado a mero elemento formal validador de uma jurisdição exercida pelo agente estatal instituído da função judicante e as partes são colaboradores da decisão do juiz. ${ }^{31}$

Todavia, a teoria de Bülow sofreu críticas em seu ponto mais discutível, acerca da implementação do protagonismo judicial que conduz ao solipsismo e ao esvaziamento do papel técnico e institucional do processo. Assim, o doutrinador alemão criou uma ciência que se destinava à instrumentalização da atividade dos juízes e não à asseguração de legitimidade da decisão fora do Estado Social. ${ }^{32}$

\footnotetext{
${ }^{28}$ BÜLOW, Oskar. Gesetz und Richeteramt. Juritsche Zeitgeschichte. Berlem: Berliner Wissenschafts, 2003 , v. 10 , p. 37.

29 ANDRADE, Francisco Rabelo Dourado de. FARIA, Guilherme Henrique Lage. O modelo social de processo: suas conjecturas sobre suas origens, desenvolvimento e crise frente ao novo paradigma do Estado Democrático de Direito. Disponível em: < http://www.publicadireito.com.br/artigos/?cod=c59115e88a6dbe2f> Acesso em 09 jul. 2018, p. 14.

30 ANDRADE, Francisco Rabelo Dourado de. FARIA, Guilherme Henrique Lage. O modelo social de processo: suas conjecturas sobre suas origens, desenvolvimento e crise frente ao novo paradigma do Estado Democrático de Direito. Disponível em: < http://www.publicadireito.com.br/artigos/?cod=c59115e88a6dbe2f> Acesso em 09 jul. 2018, p. 14-15.

31 ANDRADE, Francisco Rabelo Dourado de. FARIA, Guilherme Henrique Lage. O modelo social de processo: suas conjecturas sobre suas origens, desenvolvimento e crise frente ao novo paradigma do Estado Democrático de Direito. Disponível em: < http://www.publicadireito.com.br/artigos/?cod=c59115e88a6dbe2f> Acesso em 09 jul. 2018, p. 15.

${ }^{32}$ LEAL, André Cordeiro. A instrumentalidade do Processo em crise. Belo Horizonte: Mandamentos, 2008 , p. 65.
} 
Diante do exposto, percebe-se que as bases do socialismo processual, com poder de criação de normas pela magistratura e de controle da relação processual (protagonismo judicial), bem como o contraditório como mero elemento formal validador da atividade jurisdicional, a qual as partes são colaboradores desta atividade, pressupõe ilegitimidade quando analisadas sob o viés do Estado Democrático de Direito, em que as partes atuam decisivamente na formação dos provimento jurisdicionais.

\section{O PROCESSO NO ESTADO DEMOCRÁTICO DE DIREITO: INSTRUMENTO DE CONCRETIZAÇÃO DA DEMOCRACIA}

Com o advento do Estado Democrático de Direito, a tutela jurisdicional e o processo sofrem novas alterações em seus princípios e fundamentos. Isto porque o processo, juntamente com o Poder Judiciário, passou a ser instrumento de concretização da democracia e dos direitos fundamentais não efetivados pelo Estado.

Neste viés, cabe ao cidadão pressionar ao Estado e as instituições que cumpram seus interesses e direitos, tornando legítimo o Judiciário a concretizar a tutela dos direitos fundamentais, como executar ou formular políticas públicas. Neste sentido, o Judiciário passa a ser:

[...] órgão colocado à disposição da sociedade como instância organizada de solução de conflitos metaindividuais. Tal tarefa decorre da recente 'politização da Justiça', entendida como ativismo judicial, sempre coordenado com a atividade das partes e o respeito à Constituição na realização de políticas-públicas. ${ }^{33}$

Assim, o juiz surge como criador do direito e solucionador das legítimas pretensões sociais, realizando a democracia quando resolvido o caso apresentado ao Judiciário. ${ }^{34}$

\footnotetext{
${ }^{33}$ DIDIER JR., Fredie; ZANETI JR., Hermes. Curso de Direito Processual Civil: Processo Coletivo. $4^{\circ}$ vol. $6^{\mathrm{a}}$ ed. Salvador: JusPodivm, 2011, p. 41

${ }^{34}$ RIBEIRO, Darci Guimarães. Da tutela jurisdicional às formas de tutela. Porto Alegre: Livraria do Advogado Editora 2010, p. 96
} 
Daí surge a importância de uma tutela jurisdicional que garanta constitucionalmente ao indivíduo meios processuais para que este possa buscar os seus direitos e aprimorar o debate democrático. ${ }^{35}$

Dentre os meios processuais, a fim de concretizar democracia, encontra-se os princípios do contraditório, publicidade e fundamentação, além de um sistema policêntrico e vinculado a uma efetiva participação dos sujeitos processuais. Entretanto, antes de adentrarmos no sistema processual democrático, necessário analisar a democracia representativa e participativa, para evidenciar que a representatividade já não é mais o único meio capaz de realizar a democracia, para uma sociedade justa e solidária.

\subsection{Democracia Representativa e Participativa: o Direito de participação política}

Com o Estado Social, o Estado se torna prestador de serviços à população com o objetivo de garantir a proteção de direitos sociais, surgindo a noção de justiça social e, principalmente, o alargamento dos poderes políticos do cidadão. Assim, com o Estado Democrático de Direito o cidadão, em tese, deveria ter uma maior participação e inclusão política.

Todavia, a democracia representativa, cujo principal instrumento é o sufrágio universal, está em crise, pois não está cumprindo suas promessas, não representando a real vontade do povo. O representante político eleito sofre influências de outras áreas da sociedade, como o financeiro, mídia e da elite oligárquica brasileira, havendo um distanciamento entre as reinvindicações da sociedade e do Estado e, consequentemente, diminuindo a confiança da população no processo democrático. ${ }^{36}$

\footnotetext{
${ }^{35}$ RIBEIRO, Darci Guimarães. Da tutela jurisdicional às formas de tutela. Porto Alegre: Livraria do Advogado Editora 2010, p. 96

${ }^{36}$ SANTOS, Graciele Mafalda dos. A (IN)EFETIVIDADE DO CONTROLE DEMOCRÁTICO PELA

ADMINISTRAÇÃO PÚBLICA: uma abordagem a partir do caso do Conselho Estadual de Saúde do Rio Grande do Sul. - p. 27, 2010. Dissertação (mestrado)- UNISINOS, Programa de Pós-Graduação em Direito, São Leopoldo, 2010. Disponível em: < http://www.repositorio.jesuita.org.br/bitstream/handle/UNISINOS/3264/inefetividade_controle.pdf?sequence=1 \&isAllowed=y> Acesso em: 19 maio 2018.
} 
Como afirma Bonavides, no caso do Brasil, o país não eliminou as oligarquias, não transferiu ao povo o comando e negócios públicos e nem legitimou a presença dos partidos políticos no exercício de poder. ${ }^{37}$

Desse modo, na democracia representativa o povo se limita a escolher um representante dentre os candidatos de certos partidos políticos, inclusive alguns envolvidos em escândalos de corrupção e gestão de recursos públicos, fato esse que contribui para o aumento da desconfiança da população perante o sistema governamental. ${ }^{38}$

Percebe-se que, mesmo com o aumento dos poderes políticos do cidadão, a população não se sente representada, bem como encontra-se diante da falência institucional dos poderes legislativo e executivo, uma vez que há um excesso de processos legislativos obscuros e incoerentes, decisões do parlamento contrárias a suposta vontade popular e aumento de medidas provisórias, demonstrando a distância desses órgãos perante o cidadão. ${ }^{39}$

Diante deste cenário, necessário mais participação da população para inibir essas práticas políticas, bem como para concretizar o "bem comum" do cidadão. Para isso, defendese a combinação entre a democracia representativa e democracia participativa, proporcionando mais efetividade às demandas sociais.

Essa combinação pode se dar através de duas formas: a coexistência e complementariedade. A primeira permite a existência simultânea em diversos níveis das diferentes formas de procedimentalismo e organização política. Já a complementariedade permite que os processos de deliberação pública possam substituir parte do processo de representação e deliberação. ${ }^{40}$

\footnotetext{
${ }^{37}$ BONAVIDES, Paulo. Ciência Políticas. São Paulo: Malheiros Editores, 2003.

${ }^{38}$ SANTOS, Graciele Mafalda dos. A (IN)EFETIVIDADE DO CONTROLE DEMOCRÁTICO PELA ADMINISTRAÇÃO PÚBLICA: uma abordagem a partir do caso do Conselho Estadual de Saúde do Rio Grande do Sul. - p. 30, 2010. Dissertação (mestrado)- UNISINOS, Programa de Pós-Graduação em Direito, São Leopoldo, 2010. Disponível em: < http://www.repositorio.jesuita.org.br/bitstream/handle/UNISINOS/3264/inefetividade_controle.pdf?sequence=1 \&isAllowed=y> Acesso em: 20 maio 2018.

${ }^{39}$ RIBEIRO, Darci Guimarães. Da tutela jurisdicional às formas de tutela. Porto Alegre: Livraria do Advogado Editora 2010, p. 102.

40 SANTOS, Graciele Mafalda dos. A (IN)EFETIVIDADE DO CONTROLE DEMOCRÁTICO PELA ADMINISTRAÇÃO PÚBLICA: uma abordagem a partir do caso do Conselho Estadual de Saúde do Rio Grande do Sul. - p. 54, 2010. Dissertação (mestrado)- UNISINOS, Programa de Pós-Graduação em Direito, São Leopoldo, 2010. Disponível em: <
} 
Destarte, o cidadão se torna o legitimador do sistema, em que sem cidadania não se governa e sem povo não há soberania e poder legítimo. Assim, a democracia participativa permite que o indivíduo esteja engajado naquilo que entende ser melhor para si e à sociedade, “[...] sendo o verdadeiro protagonista dos rumos da sociedade e não mais os seus representantes." 41

A democracia participativa permite uma maior inclusão do indivíduo nas escolhas administrativas e legislativas, bem como judicial, isto por que "[...] o acesso ao Poder Judiciário é irrestrito, bastando lesão ou simples ameaça a direito para que este abra suas portas ao indivíduo, ao povo." 42

É o Poder Judiciário o mais legitimado entre as três esferas do Poder para realizar as promessas da modernidade. Isto porque a sua legitimidade está no acesso irrestrito ao Judiciário, por meio processo e de seus princípios básicos, como o contraditório, publicidade e fundamentação. ${ }^{43}$

Dessa forma, o processo se torna uma importante ferramenta posta a serviço da população para concretizar, através da tutela jurisdicional, os direitos fundamentais dos cidadãos. Assim, o processo cria o direito, se tornando garantia constitucional do Estado Democrático de Direito. ${ }^{44}$

http://www.repositorio.jesuita.org.br/bitstream/handle/UNISINOS/3264/inefetividade_controle.pdf?sequence=1 \&isAllowed=y> Acesso em: 23 maio 2018.

${ }^{41}$ RIBEIRO, Darci Guimarães. Da tutela jurisdicional às formas de tutela. Porto Alegre: Livraria do Advogado Editora 2010, p. 104.

${ }^{42}$ RIBEIRO, Darci Guimarães. Da tutela jurisdicional às formas de tutela. Porto Alegre: Livraria do Advogado Editora 2010, p. 103.

${ }^{43}$ RIBEIRO, Darci Guimarães. Da tutela jurisdicional às formas de tutela. Porto Alegre: Livraria do Advogado Editora 2010, p. 104.

${ }^{44}$ RIBEIRO, Darci Guimarães. Da tutela jurisdicional às formas de tutela. Porto Alegre: Livraria do Advogado Editora 2010, p. 105. 


\subsection{O papel da tutela jurisdicional na democracia participativa}

A democracia é um modo de vida, um regime político, bem como uma técnica social para compor interesses diversos, assim, no Estado Democrático de Direito, o seu verdadeiro objetivo é a concretização dos direitos e garantias constitucionais.

Para efetivar a concretização desses direitos, o cidadão deve participar mais do múnus público e, o Judiciário, assume uma relevância ímpar nesse papel. Isto porque, quando a Administração Pública não cumpre suas promessas, o cidadão por meio da tutela jurisdicional tem a possibilidade de conseguir realizar o direito objetivado.

A tutela jurisdicional, através do processo, se torna um valioso elemento garantidor das aspirações da sociedade, pois permite a participação do cidadão por meio do contraditório, publicidade e fundamentação, evidenciando o irrestrito acesso ao Judiciário. Neste sentido, o processo passa a ser um instrumento de concretização da democracia e, para isso, a tutela jurisdicional sofre algumas alterações, pois,

[...] a partir do paradigma jurídico-constitucional do Estado Democrático de Direito, a função jurisdicional deve ser prestada segundo o devido processo constitucional, mediante a rigorosa observância do princípio do devido processo legal na regência do contraditório, da ampla defesa, da isonomia, da fundamentação lógica dos provimentos jurisdicionais e da inafastável garantia de julgamento em bases normativas prévias (princípio da reserva legal) para a construção do ato decisório final. ${ }^{45}$

Dessa forma, o processo é um sistema de garantias de direitos fundamentais, havendo a supremacia da Constituição Federal sobre as normas processuais, devendo-se atentar para o devido processo legal e seus princípios basilares. A tutela jurisdicional, no Estado Democrático de Direito, somente se concretiza por meio de processo instaurado e desenvolvido em forma obediente aos princípios e regras constitucionais, como o juiz natural, ampla defesa, contraditório, fundamentação, a fim de efetivar as normas componentes do ordenamento jurídico. ${ }^{46}$

\footnotetext{
45 ANDRADE, Francisco Rabelo Dourado de. FARIA, Guilherme Henrique Lage. O modelo social de processo: suas conjecturas sobre suas origens, desenvolvimento e crise frente ao novo paradigma do Estado Democrático de Direito. Disponível em: < http://www.publicadireito.com.br/artigos/?cod=c59115e88a6dbe2f> Acesso em 11 jul 2018, p. 21.

${ }^{46}$ DIAS, Ronaldo Brêtas de Carvalho. Processo Constitucional e Estado Democrático de Direito. $2^{\mathrm{a}}$ ed. Belo Horizonte: Del Rey, 2012, p. 32.
} 
Assim, o processo democrático deixa de ser aquele instrumento formal que aplica o direito com rapidez, mas sim uma estrutura normativa baseada na Constituição e nos princípios constitucionais, garantindo uma adequada fruição dos direitos fundamentais em visão normativa. ${ }^{47}$

O Juiz, no processo do Estado Democrático de Direito, é servidor por dever funcional do povo e das normas constitucionais, não podendo mais construir um Direito espontaneamente surgido de sua lei íntima e de sua sensibilidade. A Jurisdição se constitui como uma atividade construída pelas partes processuais a partir dos conteúdos da lei. ${ }^{48}$

Dessa forma, o juiz, pela dimensão da Constitucionalização do Processo, participa junto com as partes da Dialética Processual Dialogal, havendo reciprocidade de diálogo entre todos aqueles que compõem o Processo. ${ }^{49}$

As partes processuais participam paritariamente no processo, através da inserção do princípio do contraditório no rol das garantias constitucionais, que decorre justamente

[...] da exigência lógica e democrática da co-participação paritária das partes, no procedimento formativo da decisão jurisdicional que postulam no processo, razão pela qual correlacionada está à garantia também constitucional da fundamentação das decisões jurisdicionais centrada na reserva legal, condição de efetividade e legitimidade democrática da atividade jurisdicional constitucionalizada. ${ }^{50}$

O princípio do contraditório é considerado uma garantia fundamental de justiça, previsto no art. $5^{\circ}$, inciso LV da nossa Carta Magna. Por meio deste princípio, o juiz tem o dever de ser imparcial e conceder às partes a possibilidade de expor suas razoes, através de provas e

\footnotetext{
47 JOSÉ COELHO NUNES, Dierle. Comparticipação e Policentrismo: horizontes para a democratização do Processo Civil. Tese (Doutorado)- Pontifica Universidade Católica de Minas Gerais. Programa de PósGraduação em Direito. Belo Horizonte, 2008, p. 194.

${ }^{48}$ DEL NEGRI, André. Controle de Constitucionalidade no Processo Legislativo: Teoria da Legitimidade Democrática. Belo Horizonte: Fórum, 2008, p. 105.

${ }^{49}$ SANTOS, Paulo Junior Trindade dos. Filosofia do direito processual (da jurisdição ao processo): o fenômeno conflitológico de interesses como gênese do direito / Paulo Junior Trindade dos Santos. Tese (Doutorado em Direito) -- Universidade do Vale do Rio dos Sinos. Programa de Pós-Graduação em Direito, São Leopoldo, RS, 2018, p. 522. Disponível em:

<file:///C:/Users/prianselmini/AppData/Local/Packages/Microsoft.MicrosoftEdge_8wekyb3d8bbwe/TempState/ Downloads/Paulo\%20Junior\%20Trindade\%20dos\%20Santos_.pdf> Acesso em 12 jul. 2018.

${ }^{50}$ DIAS, Ronaldo Brêtas de Carvalho. Processo Constitucional e Estado Democrático de Direito. $2^{\mathrm{a}}$ ed. Belo Horizonte: Del Rey, 2012, p. 93.
} 
conforme seu direito. Logo, fica evidente a igualdade entre as partes no processo do Estado Democrático de Direito. ${ }^{51}$

Este princípio não admite exceções, devendo sempre respeitado, sob pena de nulidade absoluta do processo. Nas palavras de Calamandrei, o contraditório é o princípio “[...] mais precioso e típico do processo moderno." ${ }^{, 52}$

O princípio do contraditório, juntamente com o direito de defesa, é fundamental para os litigantes do processo judicial. ${ }^{53}$ Assim, no processo do Estado Democrático de Direito, é impensável o protagonismo das partes ou do juiz, pois conduziria ao conflito entre as profissões jurídicas, além de ofuscar a necessária interdependência entre elas. A participação de todos os interessados contribui para o aperfeiçoamento do sistema jurídico, além do indivíduo ter a real possibilidade de recorrer ao Judiciário, de forma democrática, para concretizar seus direitos e garantias fundamentais.

O contraditório, nesta acepção, não é mais um elemento formal do processo, mas um elemento fundamental que abrange o objeto do processo, garantindo-se assim, ao cidadão, a devida tutela jurisdicional. O contraditório, frente ao processo, consiste em um direito de influência e um direito de ação/reação, o que se dá pela participação da parte na construção da decisão judicial. ${ }^{54}$

O princípio, a partir da metade do século XX, através de Carnelutti, Satta e Fazzalari, passou a evidenciar o seu caráter dialético e dialogal do processo em uma relação entre partes e juiz. Nas palavras de Fazzalari, os "[...] arquétipos do processo nos permitem observar: a estrutura dialética do procedimento, isto é, justamente, o contraditório". ${ }^{55}$

\footnotetext{
${ }^{51}$ RIBEIRO, Darci Guimarães. Da tutela jurisdicional às formas de tutela. Porto Alegre: Livraria do Advogado Editora 2010, p. 63-64.

52 CALAMANDREI, Piero. Processo e Democrazia. In: Opere Giuridiche, Napoli: Morano, 1965, v. I, p. 681.

${ }^{53}$ RIBEIRO, Darci Guimarães. Da tutela jurisdicional às formas de tutela. Porto Alegre: Livraria do Advogado Editora 2010, p. 65.

${ }^{54}$ SANTOS, Paulo Junior Trindade dos. Filosofia do direito processual (da jurisdição ao processo): o fenômeno conflitológico de interesses como gênese do direito / Paulo Junior Trindade dos Santos. Tese (Doutorado em Direito) -- Universidade do Vale do Rio dos Sinos. Programa de Pós-Graduação em Direito, São Leopoldo, RS, 2018, p. 517. Disponível em:

<file:///C:/Users/prianselmini/AppData/Local/Packages/Microsoft.MicrosoftEdge_8wekyb3d8bbwe/TempState/ Downloads/Paulo\%20Junior\%20Trindade\%20dos\%20Santos_.pdf> Acesso em 12 jul. 2018.

${ }^{55}$ FAZZALARI, Elio. Instituições de Direito Processual. $8^{\mathrm{a}}$ ed. Campinas: Bookseller, 2006. P. 119.
} 
Assim, o contraditório torna-se o ponto principal da investigação dialética conduzida com a colaboração reativa ${ }^{56}$ das partes processuais. Logo, a colaboração reativa constitui-se em um princípio do contraditório constitucionalizado, que se instrumentaliza como atividade operativa do Estado-Juiz, sendo que tal princípio passa a ser um momento fundamental para o Processo, tornando o fenômeno conflitológico de interesses o centro do fenômeno processual.

Se respeitado o princípio do contraditório constitucionalizado, com vistas a colaboração reativa, o Estado-Juiz pode decidir via compreensão hermenêutica, a qual nasce com o jogo dialético-dialogal, afigurando as partes como protagonistas do Processo. ${ }^{57}$

Destarte, o princípio contraditório constitucionalizado adere ao contexto social, de maneira que o objeto do processo é reconstruído e pelo objeto do debate processual e pelos atos processuais que passam a ser redimensionados pela contradição. As manifestações e alegações processuais passam por um amplo debate produzido pelo jogo dialético-dialogal assegurado pela colaboração reativa, fruto da participação das partes no processo: o processo pode, assim, ser o reflexo do direito subjetivo como lei ou por situações jurídicas subjetivas.

Por tudo isso, a democracia participativa permeia os institutos processuais e acaba oportunizando via dialeticidade processual uma governança equilibrada entre as partes, partilhando entre juiz e partes um equilíbrio entre liberdades e igualdades, tornando o processo um instrumento útil na concretização da democracia, uma vez que o indivíduo tem a possibilidade de assegurar seus direitos e garantias fundamentais, os quais o Estado não conseguiu cumprir. Assim, as aspirações do Estado Democrático de Direito podem serem efetivamente concretizadas sob o viés da tutela jurisdicional.

\subsubsection{Da politização da jurisdição à politização do Processo}

Conforme descrito nos tópicos anteriores, resta evidente a necessidade de reestruturação. Contudo, o caminho a ser percorrido em busca dessa transformação, fruto da

\footnotetext{
${ }^{56}$ PICARDI, Nicola. Jurisdição e Processo. Trad. Carlos Alberto Alvaro de Oliveira. São Paulo: Editora Forense, 2000. P.143.

${ }^{57}$ SANTOS, Paulo Junior Trindade dos. Filosofia do direito processual (da jurisdição ao processo): o fenômeno conflitológico de interesses como gênese do direito / Paulo Junior Trindade dos Santos. Tese (Doutorado em Direito) -- Universidade do Vale do Rio dos Sinos. Programa de Pós-Graduação em Direito, São Leopoldo, RS, 2018, p. 528. Disponível em:

<file:///C:/Users/prianselmini/AppData/Local/Packages/Microsoft.MicrosoftEdge_8wekyb3d8bbwe/TempState/ Downloads/Paulo\%20Junior\%20Trindade\%20dos\%20Santos_.pdf> Acesso em 12 jul. 2018.
} 
releitura da jurisdição e do processo, passa pela importância de "despolitizar a magistratura" (temática abordada por jurista do quilate de $\operatorname{Streck}^{58}$, ao tratar da filosofia da consciência) e "politizar o processo" 59 , transformando-o no espaço ideal de reconstrução social fruto da democracia participativa, ensejando decisões judiciais contextualizadas em um procedimento dialético/dialógico pelo e no processo. Nesse sentido, os fenômenos conflituais não se referem apenas ao caso concreto, mas também à composição de interesses mais vastos, coletivos e/ou generalizados, momento em que o juiz solipsista (modernidade democráticorepresentativa/verticalizada) passa a ser absorvido pela política como fruto dos debates apresentados pelos partícipes (verdadeiros cidadãos de uma democracia participativa/horizontalizada) quando da efetivação do processo, procedimento responsável por, como narrado, desaguar na decisão judicial a necessária legitimidade quando da criação de novos direitos. Para tanto, necessário se faz conceber, também, uma releitura quanto aos termos separação e divisão de poderes, ganhando relevância esse último em detrimento do primeiro, eis que os poderes do Estado não são e não devem ser estanques, portanto não devem ser silenciados quando da efetivação/ exercício das tutelas jurisdicionais vinculadas à ampla normatividade hodierna.

Pela concepção pautada nesse novo modelo jurisdicional, o Direito passa a sofrer influências interpretativas e ressementizadas diante da chamada Constitucionalização do Direito, cujo reflexo, no processo, ocorre pela publicização e socialização de suas ideologias introjetando, acentuadamente, a democracia substancial em seus institutos, o que é feito pela reestruturação jurisdicional fruto de uma democracia participativa, momento em que o processo passa a assumir a postura de veículo de garantia/realização de direitos básicos em consonância com os ditames constitucionais, oportunizando um horizonte dinâmico para a Ciência Processual.

Diante desse novo espectro jurisdicional em que a decisão judicial resta legitimada não mais/apenas pela democracia representativa verticalizada mas, sim, por uma democracia participativa horizontalizada, as partes restam alçadas a um ambiente de protagonismos em que os juízes, sem perder sua autoritas, restam submetidos às novas exigências, fazendo com que

\footnotetext{
${ }^{58}$ STRECK, L. L. O que é isto - decido conforme minha consciência? Porto Alegre: Livraria do Advogado, 2010. p. 13-14, 36-37, 55-56.

${ }^{59}$ OST, F. Il Ruolo del Giudice. Verso delle Nuove Fedeltà? Rassegna Forense, n. 3-4, p. 701-727, 2013. p. 715717.
} 
acabem intercambiando e modificando os aspectos da divisão dos poderes, uma vez tratar-se de atividade vinculada à "condição humana" ${ }^{60}$. Na proposta fruto de um direito contemporâneo, não pode/deve o juiz ser um simples funcionário da lei, eis que o processo não mais pode/ deve se comportar como um mero servente do direito material, afastado de todas as manifestações sociais e políticas ${ }^{61}$. Assim, hoje mais do que nunca a decisão judicial se apresenta revestida de uma necessária responsabilidade (direito responsivo) sociopolítica fruto de um novo jogo democrático participativo em que os cidadãos, deixando de ser apenas povo ícone/legitimador, encontram no Judiciário um novo espaço para o exercício do poder em público.

Com a evolução das teorias processuais, principalmente no que se refere à teoria monista4 e com as reformas da Codificação, em especial a Processual, premente se faz a conscientização de um cidadão ativo, procedimento que propiciará a necessária ressemantização do sujeito (relação sujeito/sujeito) que era tido como mero indivíduo (relação sujeito/objeto), reduzido ao ente. Esse novo quadro esboçado no presente estudo é reflexo da releitura constitucional do direito que, deixando de ser mera carta política, resta realçada como um importante instrumento jurídico, tornando-se responsável direta por uma ampliação normativa concebida por regras e princípios, fato que tem ensejado uma significativa ampliação interpretativa (hermenêutica filosófica), eis que agora pautada em elementos fáticos/históricos/fenomenológicos.

Como reflexo do que restava compreendido (Estado Moderno) como fenômeno do Desgoverno Judicial, que deu vazão ao solipsismo/filosofia da consciência, pautados na redução do direito à lei, pela nova teoria aqui apresentada (Estado Contemporâneo), restam ressignificados em um modelo de Governo Judicial, eis que a legitimidade, deixando de ser questionada quanto à figura do Judiciário e/ou Juiz, pela democracia participativa, resta dimensionada na decisão como um resultado hermenêutico-filosófico construído pelo/no contraditório e pela/na ampla defesa (democracia participativa horizontalizada), elevando o processo ao status de espaço ideal de construção de novos direitos ${ }^{62}$. Em relação à temática,

\footnotetext{
${ }^{60}$ CALDANi, M. A. C. El Juez, el Proceso y el Estado en la Postmodernidad. Disponível em: <http://www.carta- pacio.edu.ar/ojs/index.php/iyd/article/viewFile/829/648>. Acessado em: 31 jan. 2018. p. 2223.

${ }^{61}$ CALAMANDREI, P. Proceso y Democracia. Buenos Aires: Ediciones Jurídicas Europa-America, 1960. P. 72.

62 NIETO, A. El Desgobierno Judicial. 2. ed. Madrid: Editorial Trotta, 2010.
} 
Cruet na França já apresentava, há muito tempo, ensinamentos de contraposição do direito ao caso concreto e à impossibilidade de redução do direito ao direito legislado:

[...] o juiz não tem de impôr-nos «o seu» direito, tal como pode concebê-lo de uma maneira ideal, isto é mais ou menos subjectiva, mas tem de executar «o nosso direito», o direito que a sociedade pede e espera, o direito necessario á apparição d'um contracto novo, ao desenvolvimento d'um modo de producção industrial, à propagação d'uma descoberta scientifica, a transformação dos laços do casamento ou da família. ${ }^{63}$

O que significa "despolitizar a magistratura" e "politizar o processo" não é mais do que promover políticas como um sentimento comum de interesse dos cidadãos, pois os conflitos levados ao Judiciário não se limitam a uma reprodução do suporte fático contido nas regras, mas consubstanciam novos fenômenos pulsantes de uma sociedade complexa, o que exige do processo uma politização quando da construção da norma.

Agora é mais nítido perceber que procedimentos herdados dos últimos séculos, carregados com uma grande carga ideológica, já não mais correspondem ao que o Judiciário deve propiciar ao cidadão hoje em dia. O processo judicial exige nova reestruturação capaz de atender de forma adequada às novas realidades sensíveis da sociedade, para que seja possível superar o conceito tradicional do processo, por uma renovada dimensão que torna o processo revolucionário. Uma nova visão do processo transcende as teorias que o delimitam em ser o instrumento do direito substancial (DINAMARCO, 2009) ${ }^{64}$ da jurisdição ou mera relação jurídica, pois o processo se integrou ao sistema jurídico por meio das garantias processuais constitucionalizadas democraticamente.

De outro lado, pugna-se que os institutos processuais, quando permeados pela constitucionalização do processo, ganham tônus de democracia e participação, e, assim, "Surge uma nova alternativa para o florescimento de um espírito participativo do indivíduo na concretização da democracia contemporânea." 65 . O processo, é por sua natureza, público, o que fundamenta em sua essência um espaço de debate democrático

\footnotetext{
${ }^{63}$ CRUET, J. A Vida do Direito e a Inutilidade das Leis. São Paulo: Ibero America, 1938. p. 81-82.

${ }^{64}$ DINAMARCO, C. R. Instrumentalidade do Processo. 14. ed. São Paulo: Malheiro Editores, 2009.

${ }^{65}$ RIBEIRO, D. G. Da Tutela Jurisdicional às Formas de Tutela. Porto Alegre: Livraria do Advogado, 2010. p. 95-96.
} 
exercido pelo meio dialético do contraditório, em que são discutidos os diversos ângulos dos fatos e os desdobramentos do direito, cuja discussão legitima a atuação jurisdicional que deve observar a defesa do direito unido à realidade sensível.

\subsubsection{O Processo e sua dinâmica democrática contemporânea}

Com a manifestação de sociedades complexas que exigem uma reinvenção das instituições como restabelecimento do mundo sensível em seu aspecto de civilização e respeito ao outro, com o objetivo de uma igualdade substancial pelo reconhecimento da existência, o Processo deve exasperar o fenômeno pela aproximação fenomênica fruto da hermenêutica filosófica, capaz de reduzir as nocivas influências do cientificismo e racionalismo junto ao direito. Isso porque, fundamentalmente, a democracia substancial se exaspera em ser a melhor expressão que acompanha as contingências do ser para que ele se emancipe e que seja capaz de incessantemente reconhecer a parcela dos sem-parcela ${ }^{66}$.

Existe uma concordância racional dos indivíduos e dos grupos sociais para evitar o conflito e o dano político, preferindo-se a discussão racionalizada. Mas para que as partes discutam em vez de lutar, é necessário, em primeiro, que existam como partes. E como ficam aqueles que não são parte (ou seja, os sem-parcela?) O ser-aí reflete como ato de sua existência o fenômeno conflitológico de interesses, que torna indissociável o encontro performático e transdisciplinar das humanidades com o direito. Com esse encontro natural da expressão do serno-mundo, pode-se dizer que a democracia é o reflexo da interpretação posta pela linguagem, sendo a existência a interpretação que fundamenta a necessidade de adaptação social, pois o homem vive e interpreta. A filosofia hermenêutica apresenta como juízo reflexionante os fenômenos existenciais com sua fonte de reflexão no processo, em que os fenômenos são trazidos e desvelados e possibilitam a realização prática da filosofia por meio do debate dialético mediante os jogos de linguagem.

Segundo discorre Warat ${ }^{67}$, a democracia é uma prática política de produção de sentido, pois em nível de imaginário social, não possui o seu sentido definido. Uma determinada forma de sociedade, desse modo, é democrática na medida em que existe nela um número significativo

\footnotetext{
${ }^{66}$ RANCIÈRE, J. O Desentendimento Político e a Filosofia. São Paulo: Editora 34, 1996.

${ }^{67}$ WARAT, L. A. Introdução Geral ao Direito III: O Direito Não Estudado Pela Teoria Jurídica Moderna. Porto Alegre: Sergio Antonio Fabris Editor, 1955. p. 63.
} 
de espaços onde possam respirar os desejos desclassificados pelos sistemas simbólicos sancionados; onde possa se realizar um número indefinido de operações tendentes à libertação e transformação da linguagem, que fundamenta a heteronomia simbólica. A natureza conflitiva humana $^{68}$ exaspera esse núcleo sempre em constante movimento do social. Por isso se afirma que o processo é o local de redimensionalização do direito.

É na busca desse resgate existencial que deve o direito atuar. As relações de poder desenvolvidas na sociedade expressadas pela partilha do sensível, pela divisão, são ignoradas, não encontrando uma forma de canalização política. Isso também no que se refere à complexidade e à velocidade pelas quais são criados novos problemas e realidades. O Judiciário é assim chamado para atuar, judicializando os conflitos e dando voz aos sem-parcela. As expressões não abarcadas pelo sistema jurídico, por meio da juridicização acabam por se expressar pela judicialização do direito, em que o direito acaba por catalisar as expressões do social que, em uma pós-democracia (ou democracia consensual), o Estado ignora. O consenso social surge como um regime determinado do sensível, da existência, porém, ignora que a existência é dinâmica. O consenso vê somente um modo particular de visibilidade do direito como arkhé da comunidade. Antes de resolver os problemas dos parceiros sociais tornados sensatos, é preciso considerar que a estrutura específica da comunidade não é posta de maneira estática.

Os fenômenos conflituais trazidos à discussão no Judiciário precisam ser vistos por uma ótica transdisciplinar, em suas bases sociológicas, antropológicas e filosóficas, servindo tais estudos como elemento fulcral para a compreensão hermenêutico-fenomenológica do fenômeno como direito. O processo passa a absorver a complexidade social de forma que possibilita a adaptação existencial.

\footnotetext{
${ }^{68}$ HAN, B.-C. Psicopolítica Neoliberalismo y nuevas técnicas de poder. Barcelona: Herder Edotorial, 2014. p. $77-78$.
} 


\section{CONSIDERAÇÕES FINAIS}

Diante de todo o exposto, percebe-se que o socialismo processual, surgido como forma de equalizar as desigualdades sociais, torna-se ilegítimo frente aos princípios constitucionais do Estado Democrático de Direito. Isto porque, o socialismo processual foi construído sob o pilar do protagonismo judicial e da relação jurídico-processual. Assim, é permitida a criação de normas pela magistratura, sendo o contraditório como mero elemento formal validador da atividade jurisdicional, a qual as partes são colaboradores desta atividade.

Nesta perspectiva processual, as partes e os advogados não possuem participação igualitária no processo, sendo o juiz responsável pela direção do processo. Todavia, com o surgimento do Estado Democrático de Direito, o processo é influenciado pelos princípios constitucionais, se tornando uma importante ferramenta posta a serviço da população para concretizar, através da tutela jurisdicional, os direitos fundamentais dos cidadãos.

Dessa forma, é o Poder Judiciário o mais legitimado entre as três esferas do Poder para realizar as promessas da modernidade. Isto porque a sua legitimidade está no acesso irrestrito ao Judiciário, por meio do processo e de seus princípios básicos, como o contraditório, publicidade e fundamentação, além de um sistema policêntrico e vinculado a uma efetiva participação dos sujeitos processuais.

Como analisado, o Juiz, no processo do Estado Democrático de Direito, passa a ser um servidor por dever funcional do povo e das normas constitucionais, não podendo mais construir um Direito espontaneamente surgido de sua lei íntima e de sua sensibilidade.

Assim, o juiz participa junto com as partes da Dialética Processual Dialogal, havendo reciprocidade de diálogo entre todos aqueles que compõem o Processo, possibilitando às partes processuais participar paritariamente no processo, através da inserção do princípio do contraditório no rol das garantias constitucionais.

O princípio do contraditório deixa de ser um elemento formal do processo, passando a ser um elemento fundamental que abrange o objeto do processo, garantindo-se assim, ao cidadão, a devida tutela jurisdicional. O contraditório, frente ao processo, consiste em um 
direito de influência e um direito de ação/reação, o que se dá pela participação da parte na construção da decisão judicial.

Por isso, a participação de todos os interessados contribui para o aperfeiçoamento do sistema jurídico, além do indivíduo ter a real possibilidade de recorrer ao Judiciário, de forma democrática, para concretizar seus direitos e garantias fundamentais.

Por fim, a democracia participativa, como complemento da democracia representativa, contribui para a democratização processual, influenciando os institutos e princípios processuais, permitindo o equilíbrio entre os sujeitos processuais, via dialeticidade e do diálogo processual. Logo, o processo se torna um importante instrumento na concretização da democracia, uma vez que o indivíduo tem a possibilidade de assegurar seus direitos e garantias fundamentais, os quais o Estado não conseguiu cumprir. Assim, as aspirações do Estado Democrático de Direito podem ser efetivamente concretizadas sob o viés da tutela jurisdicional.

\section{REFERÊNCIAS}

ANDRADE, Francisco Rabelo Dourado de FARIA, Guilherme Henrique Lage. O modelo social de processo: suas conjecturas sobre suas origens, desenvolvimento e crise frente ao novo

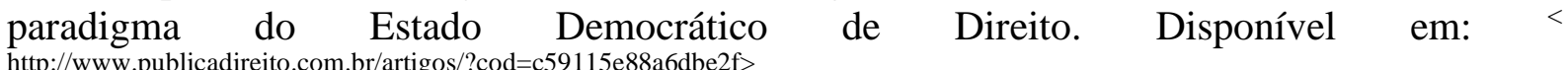
http://www.publicadireito.com.br/artigos/?cod=c59115e88a6dbe2f $>$.

BONAVIDES, Paulo. Ciência Políticas. São Paulo: Malheiros Editores, 2003.

BÜLOW, Oskar, Teoria das Exceções Processuais e dos pressupostos processuais. Campinas: LZN, 2005.

BÜLOW, Oskar. Gesetz und Richeteramt. Juritsche Zeitgeschichte. Berlem: Berliner Wissenschafts, 2003, v. 10.

CALAMANDREI, P. Proceso y Democracia. Buenos Aires: Ediciones Jurídicas EuropaAmerica, 1960. P. 72.

CALAMANDREI, Piero. Processo e Democrazia. In: Opere Giuridiche, Napoli: Morano, 1965 , v. I.

CALAMANDREI, Piero. Sul progetto preliminar Solmi. Studi sul processo civile. Padova: CEDAM, 1939, v. IV. 
CALDANI, M. A. C. El Juez, el Proceso y el Estado en la Postmodernidad. Disponível em: <http://www.carta- pacio.edu.ar/ojs/index.php/iyd/article/viewFile/829/648>. Acessado em: 31 jan. 2018. p. 22-23.

CAPPELLETTI, Mauro. Processo, ideologias e sociedade; tradução e notas do Prof. Dr. Elício de Cresci Sobrinho. - Porto Alegre: Sergio Antonio Fabris Ed., 2008.

CATTONi DE OLIVEIRA, Marcelo Andrade. Direito Processual Constitucional. Belo Horizonte: Mandamentos, 2001.

CRUET, J. A Vida do Direito e a Inutilidade das Leis. São Paulo: Ibero America, 1938. p. 8182.

DEL NEGRI, André. Controle de Constitucionalidade no Processo Legislativo: Teoria da Legitimidade Democrática. Belo Horizonte: Fórum, 2008.

DENTI, Vittorio. Processo Civile e giutizia sociale. Milano: Edizione di Comunità, 1971.

DIAS, Ronaldo Brêtas de Carvalho. Processo Constitucional e Estado Democrático de Direito. $2^{\mathrm{a}}$ ed. Belo Horizonte: Del Rey, 2012.

DIDIER JR., Fredie; ZANETI JR., Hermes. Curso de Direito Processual Civil: Processo Coletivo. $4^{\mathrm{o}}$ vol. $6^{\mathrm{a}}$ ed. Salvador: JusPodivm, 2011.

DINAMARCO, C. R. Instrumentalidade do Processo. 14. ed. São Paulo: Malheiro Editores, 2009.

DINAMARCO, Cândido Rangel. A instrumentalidade do processo. São Paulo: Malheiros, 2001.

FAZZALARI, Elio. Instituições de Direito Processual. $8^{\mathrm{a}}$ ed. Campinas: Bookseller, 2006.

HAN, B.-C. Psicopolítica Neoliberalismo y nuevas técnicas de poder. Barcelona: Herder Edotorial, 2014. p. 77-78.

JOSÉ COELHO NUNES, Dierle. Comparticipação e Policentrismo: horizontes para a democratização do Processo Civil. Tese (Doutorado)- Pontifica Universidade Católica de Minas Gerais. Programa de Pós-Graduação em Direito. Belo Horizonte, 2008.

KLEIN, Franz. Zeit- und Geistesströmungen im prozesse. Frankfurt am Main: Vitorio Klostermann, 1958.

LEAL, André Cordeiro. A instrumentalidade do Processo em crise. Belo Horizonte: Mandamentos, 2008.

MAUS, Ingeborg. Judiciario como superego da sociedade: o papel da atividade jurisprudencial da "sociedade órfã". Novos estudos CEBRAP, n. 58, p. 97-98, nov. 2000.

MENGER, Anton. El derecho civil e los pobres. Atalya: Buenos Ayres, 1947.

NIETO, A. El Desgobierno Judicial. 2. ed. Madrid: Editorial Trotta, 2010. 
NUNES, Dierle José Coelho. Processo Jurisdicional Democrático. Curitiba: Juruá, 2008.

OST, F. Il Ruolo del Giudice. Verso delle Nuove Fedeltà? Rassegna Forense, n. 3-4, p. 701727, 2013. p. 715-717.

PICARDI, Nicola. Jurisdição e Processo. Trad. Carlos Alberto Alvaro de Oliveira. São Paulo: Editora Forense, 2000.

RANCIÈRE, J. O Desentendimento Político e a Filosofia. São Paulo: Editora 34, 1996.

RIBEIRO, D. G. Da Tutela Jurisdicional às Formas de Tutela. Porto Alegre: Livraria do Advogado, 2010. p. 95-96.

RIBEIRO, Darci Guimarães. Da tutela jurisdicional às formas de tutela. Porto Alegre: Livraria do Advogado Editora 2010.

SANTOS, Graciele Mafalda dos. A (IN)EFETIVIDADE DO CONTROLE DEMOCRÁTICO PELA ADMINISTRAÇÃO PÚBLICA: uma abordagem a partir do caso do Conselho Estadual de Saúde do Rio Grande do Sul. - p. 54, 2010. Dissertação (mestrado)- UNISINOS, Programa de Pós-Graduação em Direito, São Leopoldo, 2010. Disponível em: < http://www.repositorio.jesuita.org.br/bitstream/handle/UNISINOS/3264/inefetividade_control e.pdf? sequence $=1 \&$ isAllowed $=y>$.

SANTOS, Paulo Junior Trindade dos. Filosofia do direito processual (da jurisdição ao processo): o fenômeno conflitológico de interesses como gênese do direito. Tese (Doutorado em Direito) -- Universidade do Vale do Rio dos Sinos. Programa de Pós-Graduação em Direito, São Leopoldo, RS, 2018. Disponível em: <file:///C:/Users/prianselmini/AppData/Local/Packages/Microsoft.MicrosoftEdge_8wekyb3d 8bbwe/TempState/Downloads/Paulo\%20Junior\%20Trindade\%20dos\%20Santos_.pdf> Acesso em 12 jul. 2018.

SPRUNG, Rainer. Os fundamentos do processo civil austríaco. Revista de Processo, São Paulo. Revista dos Tribunais, $\mathrm{n}^{\circ}$ 17, p. 148, jan./mar. 1980.

STRECK, L. L. O que é isto - decido conforme minha consciência? Porto Alegre: Livraria do Advogado, 2010. p. 13-14, 36-37, 55-56.

TROCKER, Nicolo. Processo Civile e Costituzione. Probleme de diritto tedesco e italiano. Milano: Giuffrè, 1974.

WARAT, L. A. Introdução Geral ao Direito III: O Direito Não Estudado Pela Teoria Jurídica Moderna. Porto Alegre: Sergio Antonio Fabris Editor, 1955. p. 63.

Data de submissão: 07/01/2019

Data de Aceite: 05/12/2019 